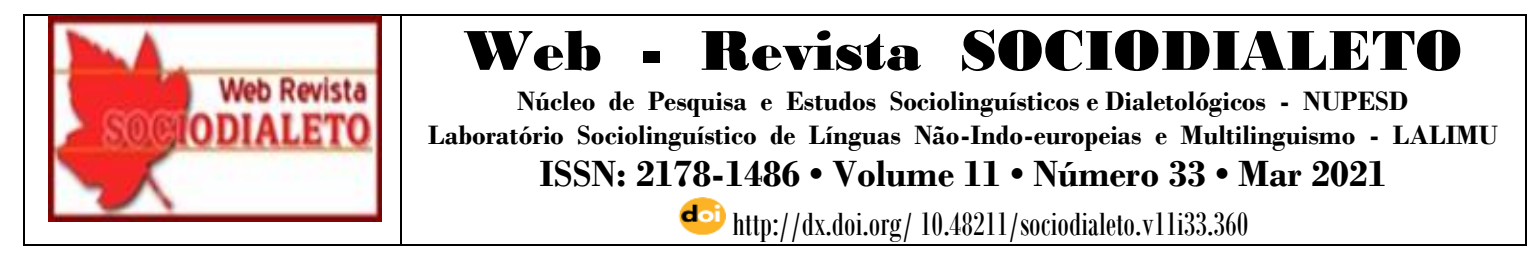

\title{
CRENÇAS E ATITUDES LINGUÍSTICAS DE ACADÊMICOS DE LETRAS E MATEMÁTICA ACERCA DE ANGLICISMOS NO PORTUGUÊS BRASILEIRO
}

\author{
LINGUISTIC BELIEFS AND ATTIUDES OF STUDENTS OF LANGUAGES AND MATHEMATICS ABOUT ANGLLCISMS IN \\ BRAZILIAN PORTUGUESE
}

\author{
Marília Silva Vieira (UEG) ${ }^{1}$ \\ vieirasmarilia@gmail.com
}

\author{
Aline Kelen Rodrigues da Silva (UEG) ${ }^{2}$ \\ alinekelen98@gmail.com
}

\begin{abstract}
RESUMO: O trabalho objetiva, sob a ótica da Sociolinguística Variacionista, analisar as crenças e atitudes linguísticas tomadas por acadêmicas de Letras e Matemática, falantes de Português Brasileiro (PB), acerca da inserção de anglicismos. Apresentando os conceitos de prestígio e purismo linguísticos. Fundamenta-se em Labov, Wenreich e Herzog (2006[1968]); Labov (1964), Biderman (2001), Bagno (1999;2001), Câmara Jr (1986), Carvalho (2002), Faraco (2001) e Fernández (1998). Em uma perspectiva sociolinguística, é possível percebermos como funciona esse processo de intercâmbio linguístico, essa mistura de línguas no âmbito social da fala. Dessa forma, esta pesquisa pode contribuir para mostrar se a Língua Inglesa, que está cada vez mais presente em nosso vocabulário, ainda causa uma estranheza em pessoas de uma área de estudo que não tem um contato tão intenso com o inglês, como o que o curso de Letras apresenta. Através disso, será possível verificar as diferentes atitudes que são tomadas por pessoas de outro campo de estudo quando entram em contato com essa língua. Utilizando como método de recolha dos dados a técnica de Matched Guise, adaptada em um formulário, na plataforma digital Google Forms. Mediante as atitudes linguísticas que foram manifestadas pelas participantes, os resultados sinalizaram que o processo de aceitação e/ou rejeição dos anglicismos no PB é condicionado, sobretudo, por fatores sociais. Cada grupo de juízes, os da Matemática e os da Letras, manifestaram níveis de prestígio diferentes acerca dos anglicismos presentes no teste.
\end{abstract}

PALAVRAS-CHAVE: Crenças e Atitudes. Anglicismos. Português Brasileiro.

\begin{abstract}
The work aims, form the perspective of Variotionist Sociolinguistics, to amalize the linguistic beliefs and attitudes taken by academics of Modern Languages (Portuguese and English) and Math, speakers of Brazilian Portuguse (PB), about the insertion of anglicisms. Introducing the concepts of linguistic prestige and purism. It is based on LABOV, HERZOG AND WEINREICH (2006 [1968]); LABOV (1964), BIDERMAN (2001), BAGNO (1999; 2001), CÂMARA JR (1986), CARVALHO (2002), FARACO (2001) and FERNÁNDEZ (1998). From a sociolinguistic perspective, it is possible to see how this process of linguistic exchange works, this mixture of languages in the social sphere of speech. In this way, this research can contribute to show whether the English language, which is increasingly present in our vocabulary, still causes a strangeness in people from an area of study that does not have such intense contact with English, as what the course of Modern Languages (Portuguese and English). Through this, it will be possible to verify the different attitudes that are taken by people from another field of study when

\footnotetext{
${ }^{1}$ Professora na Universidade Estadual de Goiás (UEG/Cora Coralina).

2 Acadêmica do Curso de Letras-Língua Portuguesa, Língua Inglesa e suas respectivas Literaturas 2018/2021, na Universidade Estadual de Goiás (UEG-Cidade de Goiás).
} 


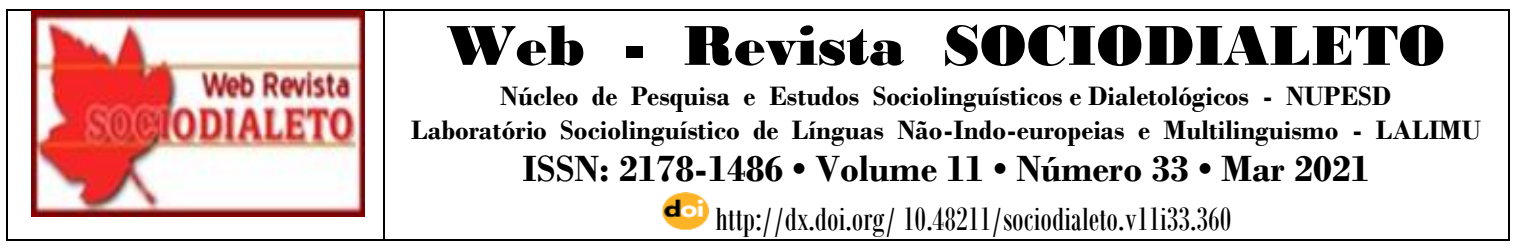

they come into contact with that language. Using the Matched Guise technique as a method of data collection, adapted into a form, on the Google Forms digital platform. Through the linguistic attitudes that were expressed by the participants, the results signaled that the process of acceptance and / or rejection of anglicisms in BP is conditioned, above all, by social factors. Each group of judges, those of Modern Languages (Portuguese and English) and Math, expressed different degrees of prestige regarding the anglicisms present in the test.

KEYWORDS: Beliefs and attitudes. Anglicismos. Brasilian Portuguese.

\section{1-INTRODUÇÃo}

O léxico do Português do Brasileiro (PB) conta com um número cada vez maior de palavras da Língua Inglesa. Isso acontece, historicamente, devido a uma série de fatores, como a globalização, os avanços tecnológicos, a grande influência das mídias em massa, a necessidade de se comunicar, o contato linguístico, dentre outros. Todo esse panorama favorece o uso de estrangeirismos, especificamente, o de anglicismos, por falantes brasileiros. Esse choque de culturas entre as línguas é uma das áreas de interesse da Sociolinguística, que procura explicar como esse processo ocorre.

Esse empréstimo linguístico sempre existiu na história das línguas e, no Português Brasileiro (doravante PB), não é diferente. Contudo, ainda pode haver rechaço quanto aos anglicismos, devido ao que Mattoso Câmara Jr. (1986, p. 202) denominou "purismo linguístico": "uma atitude de extremado respeito às formas linguísticas consagradas pela tradição do idioma, que, muitas vezes, se assume na língua literária; a língua é considerada à maneira de uma água cristalina e pura, que não deve ser contaminada". Logo, o purista acredita que o sistema linguístico do PB pode ser afetado pela inserção de estrangeirismos, de modo a causar uma possível descaracterização da língua nacional.

Segundo Bagno (2001, p. 49), estrangeirismos "são termos e expressões de outras línguas que estão sendo cada vez mais empregados na língua falada e escrita no Brasil. Mais precisamente, concentram-se nas palavras de origem inglesa". Bagno (1999, p. 23) discorda de quem defende que a inserção de anglicismos no PB causará sua ruína e afirma que os anglicismos não têm força destruidora para causar a descaracterização do Português, como defendem os puristas e conservadores. 


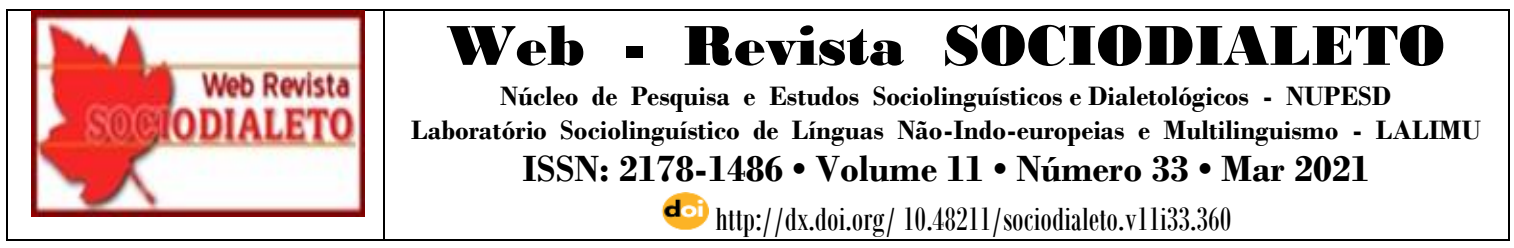

Sob um prisma descritivo, os estrangeirismos contribuem para reforçar o elo entre a cultura e o léxico da língua. Atualmente, por conta do avanço tecnológico na comunicação, tornou-se uma necessidade básica que profissionais de várias áreas tenham domínio de uma segunda língua, geralmente, a Inglesa, por ser considerada universal. Quem domina uma língua estrangeira é visto como certa distinção e prestígio social. Para Rajagopalan (2003), as pessoas entendem a aprendizagem de uma segunda língua a oportunidade de subir na vida, pois, a língua estrangeira "sempre representou prestígio".

Nessa perspectiva, a presente pesquisa justifica-se por observar e analisar as crenças e atitudes linguísticas de acadêmicas de Letras e Matemática de uma universidade pública do estado de Goiás acerca de anglicismos. Para isso, serão respondidas algumas questões, tais como: 1) Como essas acadêmicas, pertencentes a diferentes áreas de estudo, reagirão aos anglicismos do teste? 2) Como essas atitudes podem ser interpretadas em relação a um possível prestígio do PB e do inglês? 3) As acadêmicas de Matemática, por não terem contato com a Linguística, estariam mais propensas a demonstrar purismo linguístico?

\section{2-FUNDAMENTAÇÃO TEÓRICA}

O presente trabalho respalda-se, teoricamente, nos estudos de mudança linguística, desenvolvidos sob a ótica da Sociolinguística Variacionista (LABOV,1994, 2004, 2006, 2008). A partir desse modelo que visa analisar a relação entre a estrutura linguística e a social, objetivamos observar como se dá a aceitação ou a rejeição da inserção dos anglicismos no PB. Nessa perspectiva, com base nas premissas de Weinreich, Labov e Herzog (2006 [1968]), apresentam-se alguns dos princípios basilares para o estudo da variação e mudança linguística:

"Sobrevir que a mudança linguística começa quando a generalização de uma alternância particular, num dado subgrupo da comunidade linguística, toma uma direção e assume um caráter de uma diferenciação ordenada. Outro ponto consiste em que a estrutura linguística inclui a diferenciação ordenada dos falantes e dos estilos através de regras que governam a comunidade linguística. Sendo que o domínio do falante nativo sobre a língua inclui o controle de estruturas 


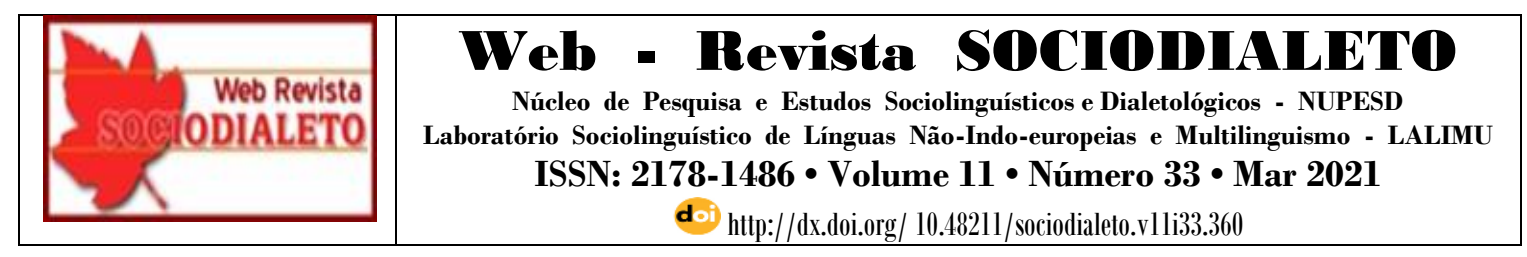

heterogêneas. Chama-se, também, atenção ao fator de que nem toda variabilidade e heterogeneidade na estrutura linguística implicam mudança, mas toda mudança implica variabilidade e heterogeneidade." (WEINREICH, LABOV E HERZOG, 2006 [1968], p. 125-126).

Labov, a partir dos princípios gerais, sistematizou a estratégia para o estudo da mudança linguística. Para ele, este modelo "requer como ponto de partida a variação em uma ou mais palavras na fala de um ou mais indivíduos." (LABOV, 2008[1972], p. 19). Em outras palavras, para o linguista, a mudança implica a variação dentro de uma comunidade de fala.

A mudança linguística se reflete no uso de anglicismos incorporados ao PB e que se representam, antes de tudo, mudanças de hábitos, de valores e de visões de mundo, tais como os itens lexicais adotados em virtude da pandemia da Covid-19. Esse intercâmbio linguístico proveniente do contato cultural, cada vez maior entre os povos, revela como os itens lexicais resultam de trocas de elementos culturais entre os povos pertencentes. Além disso, é preciso ressaltar que os empréstimos linguísticos são tão antigos quanto a história da própria Língua Portuguesa, produtos de um processo histórico constante, que, consequentemente, geram mudanças linguísticas em todas as áreas, inclusive no léxico da língua. Portanto, percebe-se, como aponta Carvalho (2009), que "o sistema lexical é a soma de experiências da sociedade e de sua cultura".

O léxico do PB é repleto de estrangeirismos, das mais variadas línguas, como do latim popular (ou sermo vulgaris), que, segundo Carvalho (2009), "tem sua base lexical formada por palavras que passaram por transformações no romance lusitânico”. Assim, essas palavras modificadas constituem o padrão fonético e morfológico do PB. Palavras do latim popular, como bucca (boca), passaram por esse processo de modificação e adaptação, até se tornarem palavras do nosso português. O Latim é a língua origem de grande parte dos vocábulos do PB, entretanto, o acervo de palavras brasileiras oriundas de outras línguas é extenso, como do francês em "abajur", do italiano, como em "lasanha", do africano, como em "acarajé", do japonês em "caratê", do inglês em "pendrive", dentre outros. 


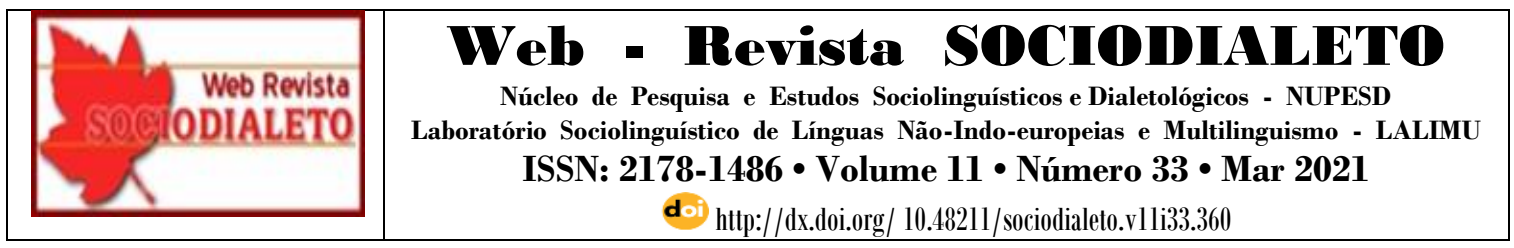

Para Labov (1994), "não se deve parar no que é estritamente linguístico”. Isso evidencia que, quanto maior o contato entre os povos, maior serão as trocas linguísticas, o que representa um gatilho para a mudança. Nesse caso, a língua recebe influências diversas no seu uso cotidiano. Na visão de Faraco (2001), estrangeirismos são elementos provenientes de outras línguas que são empregados dentro de uma língua, um fenômeno frequente no contato entre as comunidades linguísticas.

No presente trabalho, serão enfatizados os itens lexicais provenientes da Língua Inglesa, chamados de anglicismos. $\mathrm{O}$ forte contato com a cultura norte-americana, o poder econômico dos Estados Unidos da América e o desenvolvimento das tecnologias são alguns fatores que contribuíram para o uso de termos em inglês e ao seu uso em escala global. Dentro desse contexto, é importante ressaltar que os anglicismos podem ser categorizados de acordo com seu grau de enraizamento na língua de origem.

Biderman (2001), apresenta três categorias de estrangeirismos: a primeira é o decalque, que também pode ser chamado de calque ou calco, que corresponde à versão literal do lexema-modelo concretizado, e consiste em criar novos termos por meio da tradução de vocábulos estrangeiros, mantendo-se o sentido e a estrutura da língua origem, como em cartão de credito, calco de credit card; a segunda categoria é a adaptação ou adequação da forma estrangeira à fonética e à ortografia brasileiras, oficializando-se a pronúncia de acordo com a fonética de nossa língua materna, como de drink para drinque; e a última categoria é a incorporação da palavra em sua grafia original, como best sellers, por exemplo.

Sandmann (1997), aponta três grupos de neologismos por empréstimos: lexical, semântico e estrutural. O primeiro ocorre quando há a incorporação da palavra em sua grafia original (pizza); o segundo, no sentido semântico, é a tradução ou a substituição de morfemas, de modo que se mantenham as marcas de importação, ou seja, o sentido e a estrutura da língua origem se mantém (hot dog-cachorro-quente); no último caso, de nível estrutural, é a importação de modelo não vernáculo, como "determinante + determinado" (video conference-videoconferência). 


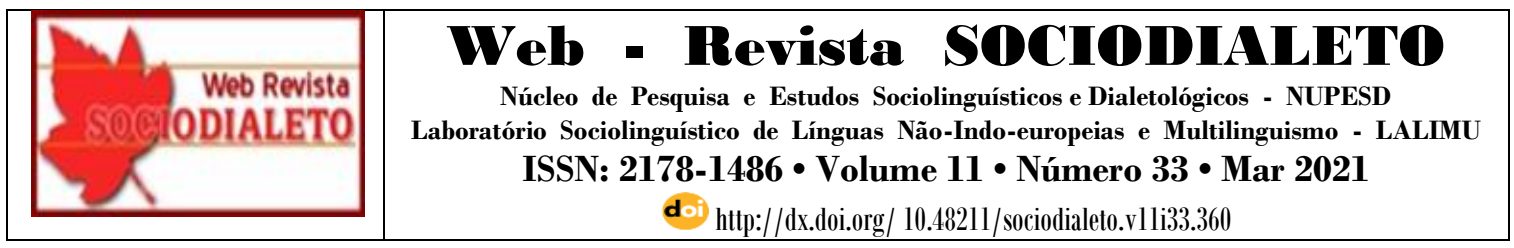

Dessa forma, a assimilação de estrangeirismos, em alguns casos, conjectura o que Biderman (2001) classifica como "adaptação da forma estrangeira à fonética e à ortografia brasileira e à incorporação do vocábulo em sua grafia original”. Ocorre, pois, uma aceitação por parte da comunidade linguística perante tal conceito e a incorporação do item emprestado em sua grafia original, sem adaptações. Todavia, assim como pode ocorrer uma aceitação do item lexical pela comunidade linguística, pode haver, também, uma rejeição dele. A esse respeito, Carvalho (2002) evidencia que "um termo estrangeiro pode ser adotado, substituído ou rejeitado pela comunidade linguística”.

\section{3-CRENÇAS E ATITUDES}

Como já mencionado por Weinreich, Labov e Herzog (2006), a avaliação é uma das etapas de grande relevância para o processo de mudança linguística. Logo, os estudos de percepção, concentrados na terceira onda da Sociolinguística (ECKERT, 2000, 2012), investigam os comportamentos linguísticos por intermédio das avaliações realizadas por indivíduos perante a inserção de um novo termo linguístico dentro da comunidade linguística. Para isso, é preciso observar como ocorre a mudança linguística e analisar a estrutura linguística dos usuários e dos estilos que, por meio de regras intra e extralinguísticas, governam a variação em sua comunidade linguística. No que tange ao uso de anglicismos, as crenças e atitudes linguísticas dos falantes de PB podem sinalizar o ritmo da mudança. Para Moreno Fernández (1998, p. 179),

A atitude linguística é uma manifestação da atitude social dos indivíduos, distinguida por centrar-se e referenciar-se tanto a língua como o uso que ela tem na sociedade, e ao falar de língua incluímos qualquer tipo de variedade linguística [...]. (FERNÁNDEZ, 1998, p. 179. (tradução nossa) $)^{3}$

\footnotetext{
3 Trecho original: “ La actitud lingüística es una manifestación de la actitud social de los individuos, distinguida por centrarse y referirse específicamente tanto a la lengua como al uso que de ella se hace em sociedad, y al hablar de <<lengua>> incluimos cuaquier variedad lingüística." (FERNÁNDEZ, 1998, p. 179).
} 


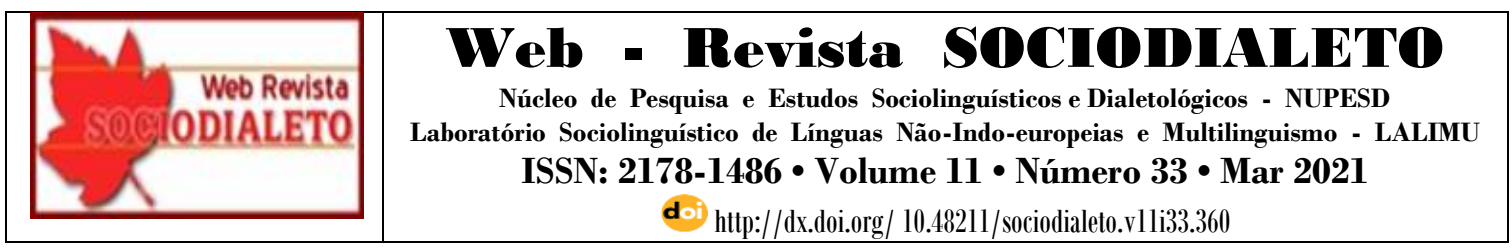

As atitudes têm formas diversas de se manifestar: López Morales aborda as atitudes positivas e negativas, que se expressam de inúmeras formas, diante de diferentes tipos de realidades sociolinguísticas. Se a atitude do falante acerca de determinado termo ou expressão em inglês é positiva, a incorporação desse termo ao léxico pode ocorrer de forma mais rápida. Uma atitude negativa, no entanto, pode levar ao seu abandono do item lexical, impedindo a mudança.

Segundo Moreno Fernández (1998), as atitudes, além de serem portadoras de formas e atributos linguísticos, também transmitem significados, conotações sociais e valores sentimentais. Em termos gerais, acredita-se que as atitudes linguísticas implicam diretamente a presença de vários elementos ou subcomponentes: valoração (componente afetivo), um saber ou crença (componente cognitivo) e uma conduta (componente conotativo).

Para melhor compreensão de como ocorre o processo da língua em seu uso social, López Morales propôs uma representação entre a relação das crenças linguísticas e as atitudes linguísticas:

Figura 1: Relação entre crença e atitude linguística segundo Lopes Morales LA LENGUA EN SU USO SOCIAL

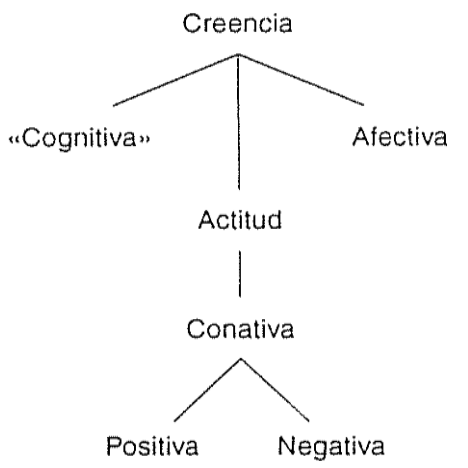

Fonte: Fernández (1998, p.185) 


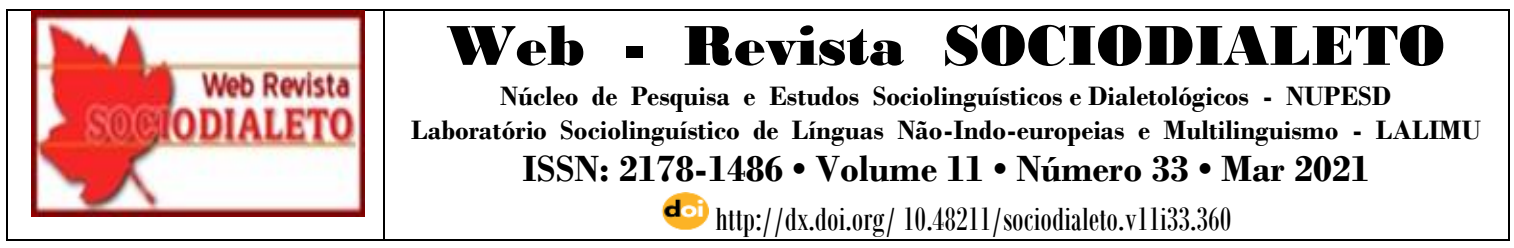

De acordo com López Morales, as crenças linguísticas de um indivíduo ou grupo levam ao surgimento das atitudes linguísticas. Por meio da representação, é possível compreender que as crenças linguísticas (componentes cognitivo e valorativo), determinam as atitudes linguísticas que conduzem os indivíduos a condutas, e podem ser positivas ou negativas. Mediante tal fato, é possível a compreensão de questões que podem estar relacionadas a determinadas atitudes linguísticas manifestadas por um grupo ou por uma comunidade de fala.

Nessa perspectiva, as crenças e atitudes dos falantes do PB acerca dos anglicismos serão analisadas à luz do conceito de prestígio. O prestígio linguístico pode ser considerado tanto como uma conduta quanto uma atitude, é algo que se tem e que se demonstra e, também, algo que se concede. De acordo com Moreno Fernández (1998), o prestígio pode ser definido como "um processo de concessão de estima e respeito que há em indivíduos ou grupos, que reúnem certas características e que leva à imitação das condutas e de crenças desses indivíduos ou grupos". As normas de prestígio podem variar de um grupo social para outro e, para descobrir a formulação geral de normas que regem uma comunidade de fala, primeiramente, é preciso descobrir o que caracteriza cada grupo social que compõe essa comunidade de fala.

\section{4-METODOLOGIA}

O corpus desta pesquisa constitui-se de dados obtidos por meio de dois estímulos linguísticos, especialmente gravados para o experimento, a partir de duas versões de um texto elaborado especificamente para a aplicação do teste. A primeira versão do texto foi formulada apenas com palavras do PB; na segunda, é feita a substituição de alguns itens lexicais da língua materna por anglicismos.

As duas versões do texto são avaliadas por 12 graduandas de uma universidade pública de Goiás. Metade delas cursam graduação em Letras e a outra metade, Matemática. Todas elas estão matriculadas no terceiro período da Licenciatura. 


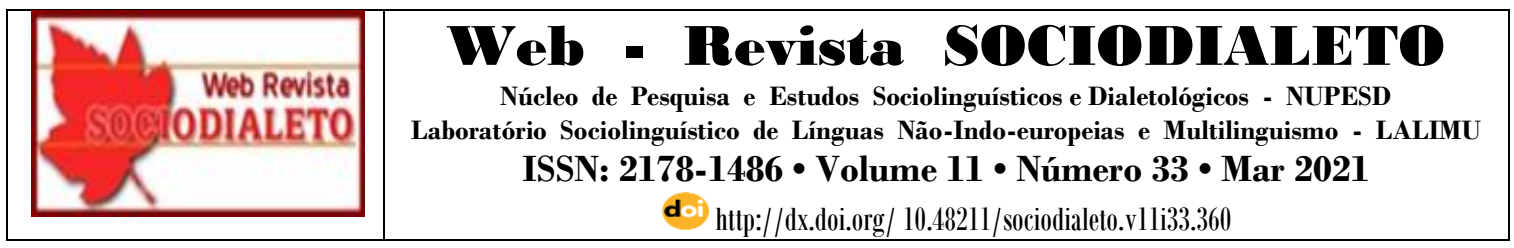

A princípio, o instrumento utilizado para obter os dados desta pesquisa foi um formulário elaborado na plataforma digital Google Forms, adaptado da técnica matched guise, de Lambert (2003 [1967]), precursor dos estudos sobre atitudes linguísticas. Em um segundo momento, as participantes responderam outro formulário, disponibilizado na mesma plataforma digital, Google Forms, cujo propósito era a medição direta.

A técnica Matched Guise surgiu nos estudos da Psicologia Social, a qual, segundo Lambert e Lambert (1972, p. 7), é “o estudo experimental dos indivíduos, examinados no seu enquadramento social e cultural", sendo atribuição do psicólogo social buscar descrever e explicar os efeitos psicológicos do contato social e o próprio processo social. Até a década de 60, esses estudos não se preocupavam com o aspecto sociocultural da linguagem nem com questões sociolinguísticas. A língua era utilizada somente como um instrumento para obter dados. Foi Lambert (2003[1967]), que se interessou pelos aspectos social, ideológico e cultural da linguagem.

Essa técnica é muito comum quando se opta pelo método de medição indireta, que consiste em inferir as atitudes linguísticas, apresentado aos juízes estímulos com o conteúdo que se objetiva analisar. Baseados em suas crenças linguísticas, eles avaliarão os estímulos e os julgarão, sem que tenham consciência do propósito da investigação. Em sua origem, consiste em utilizar falantes bilíngues, a fim de refletir sobre as crenças e atitudes linguísticas em relação ao falante, quando opta por cada uma das línguas em questão. Para o presente teste, solicitou-se que uma voluntária de 39 anos, goiana, graduada e doutora em Letras e professora de inglês, gravasse os estímulos: o primeiro, em que constam apenas palavras em português e o segundo, com a inserção de anglicismos. Os estímulos foram produzidos de modo a se aproximar da fala cotidiana e espontânea:

\section{Estímulo 1:}

"Gente, resolvi dar uma virada na minha vida! Me sentia muito mal, já não gostava do meu corpo, do meu estilo de roupa, de mais nada. Aí, um dia, quando estava indo para o trabalho, vi uma placa com a seguinte 


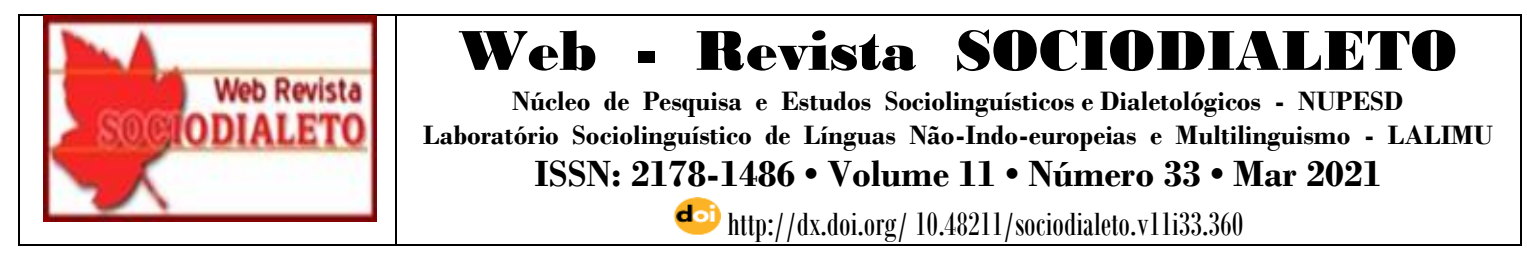

frase: "Sua vida é feita de escolhas, faça a sua e seja feliz!" A parti daí, eu parei de ficar triste por coisas que eram fáceis de ser resolvidas, decidi mudar, comecei uma dieta com pouco carboidrato, que é excelente, por sinal! Passei a tomar vitaminas e a fazer exercícios toda manhã. Comecei a cuidar da saúde do meu corpo, mas sem essa obsessão de ficar modelada, sabe!? Optei por ir para o trabalho de bicicleta, porque, além de fazer bem para mim, faz bem para o bolso e para o meio ambiente também. Aí, mudei meu estilo de roupa também. Mas não para ficar na moda, como essas modelos de revistas, mas, sim, para me sentir bem com roupas que definem minha essência, meu verdadeiro eu! Comecei a sair mais com meus amigos para a noite, curtir, sorrir com eles, até marcamos uns esquemas depois de alguns goles".

\section{Estímulo 2:}

"Gente, resolvi dar um up na minha vida! Me sentia muito na bad, já não gostava do meu corpo, do meu style de roupa, de mais nada, sabe!? Até que um dia, quando eu estava indo para o trabalho eu vi em um outdoor a seguinte frase: "Sua vida é feita de escolhas, faça sua escolha e fique happy!" A parti daí, parei de ficar sad por coisas que eram fáceis de ser resolvidas, foi aí que decidi começar uma dieta LowCarb, que é excelente, por sinal! Passei a tomar shake diet e a fazer exercícios físicos toda manhã. Passei a cuidar da saúde do meu corpo, mas sem essa obsessão de ser fitness, sabe!? Optei por ir ao trabalho de bike, porque, além fazer bem para mim, faz bem paro o bolso e para o meio ambiente também! Aí mudei meu design de roupas, mas não para ficar fashion como essas top models de revista, mas, sim, para me sentir bem, com looks que definem minha essência, meu verdadeiro eu! Comecei a sair com meus melhores amigos para a night, a curtir mais, sorrir mais com os meus best friends, até tivemos alguns afters após alguns drinks".

Como dito anteriormente, Biderman (2001), apresenta três categorias de estrangeirismos: a primeira é o decalque, representado, no teste, pelas palavras, estilo (style), dieta com baixo carboidrato (Low Carb), melhores amigos (best friends); a segunda é a adaptação ou adequação da forma estrangeira à fonética e à ortografia brasileiras, que, no teste, são exemplificadas por drinks (drinque)s; a terceira categoria é a incorporação da palavra em sua grafia original, como up sad, bad, happy, outdoor, fitness, bike, design, look, top model, shake diet, fashion e afters, empregadas no teste. 


\begin{tabular}{|c|c|}
\hline $\begin{array}{l}\text { Web Revista } \\
\text { ODIALETO }\end{array}$ & 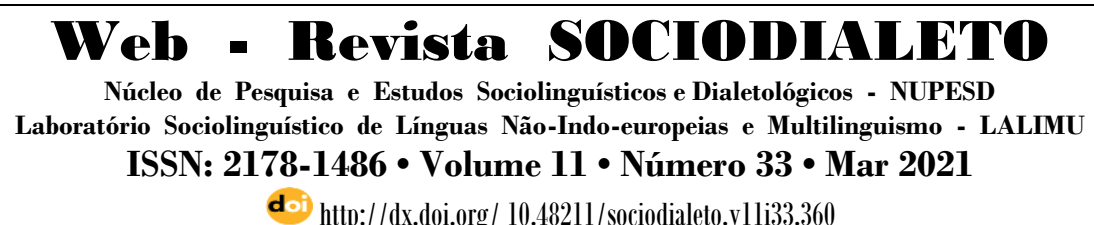 \\
\hline
\end{tabular}

Depois da gravação dos áudios, foi formulado o teste, com base em características vinculadas a três categorias, propostas por Lambert (2003): competência, representada pelo atributo inteligência; integridade pessoal, representada pelo atributo responsabilidade e atratividade social atribuída à elegância. Como já dito anteriormente, na perspectiva de Rajagopalan (2003), de quem domina uma segunda língua detém prestígio social. Logo, acredita-se que as informantes irão considerar a fala com anglicismos mais inteligente. Ao considerarem a fala com anglicismos mais inteligente, acredita-se, também, que irão avaliar a falante do estímulo como mais responsável, em uma extensão de crenças positivas acerca dos anglicismos.

Foram, ao todo, 3 quesitos de avaliação para cada um dos estímulos, distribuídos em uma escala de diferencial semântico, com 5 opções, de modo que 1 e 2 são consideradas mais negativas, 3 , a mediana, 4 e 5, as mais positivas na escala de avaliação. Desse modo, cada uma das informantes escolheu a opção que melhor representa sua percepção acerca dos estímulos.

Figura 2 - Parte do formulário apresentado às informantes

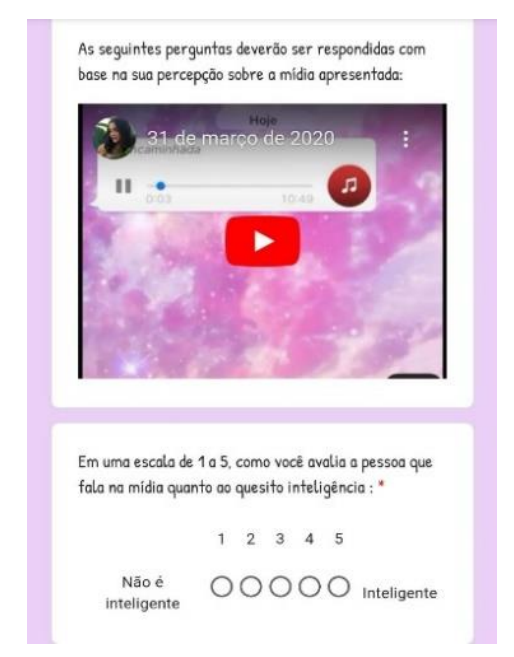

Fonte: Dados da presente pesquisa

A figura apresenta parte do modelo do formulário utilizado nesta pesquisa, a partir do qual as participantes emitiram seus juízos de valor após ouvir cada áudio. 


\begin{tabular}{|c|c|}
\hline $\begin{array}{l}\text { Web Revista } \\
\text { ODIALETO }\end{array}$ & 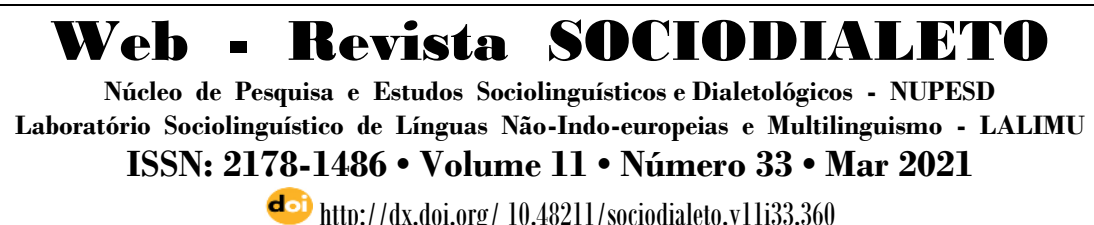 \\
\hline
\end{tabular}

Primeiramente, era exibido o estímulo integralmente em português e, posteriormente, aquele com a inserção de anglicismos.

\section{5-RESULTADOS E ANÁLISE DOS DADOS}

Com base nos dados recolhidos do teste, verificamos as escolhas feitas pelas julgadoras de cada curso, com base na percepção que tiveram sobre os estímulos. Em seguida foram montados gráficos com a distribuição das escolhas em relação a cada fala.

\section{1-Análise da percepção das acadêmicas de Letras}

Primeiramente, serão exibidos os resultados obtidos por meio avaliação das 6 acadêmicas do curso de Letras. Para cada atributo social que compõe o teste, serão comparados os resultados referentes ao estímulo 1, com palavras vernáculas, e ao estímulo 2, com anglicismos.

\section{Gráfico 1: Dados referentes à Inteligência - Português}

\section{Estímulo totalmente em Português}

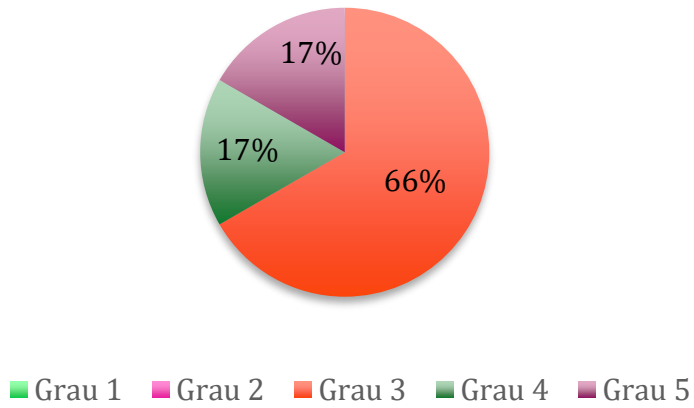

Fonte: Dados da presente pesquisa

Ao observar os dados apresentados no gráfico, analisando as escolhas feitas pelas julgadoras referentes ao estímulo em que constam apenas palavras do PB, verifica-se que $66 \%$ das juízas optaram pela opção 3 no quesito inteligência. 


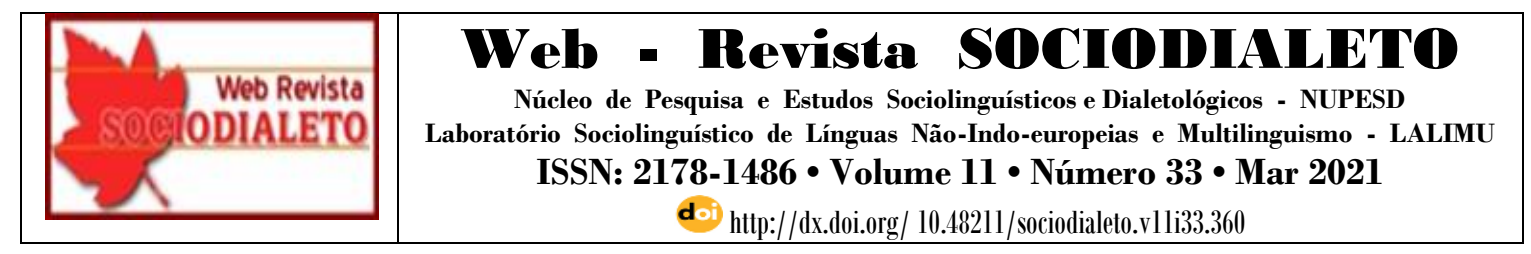

\section{Gráfico 2: Dados referentes à Inteligência - Anglicismos}

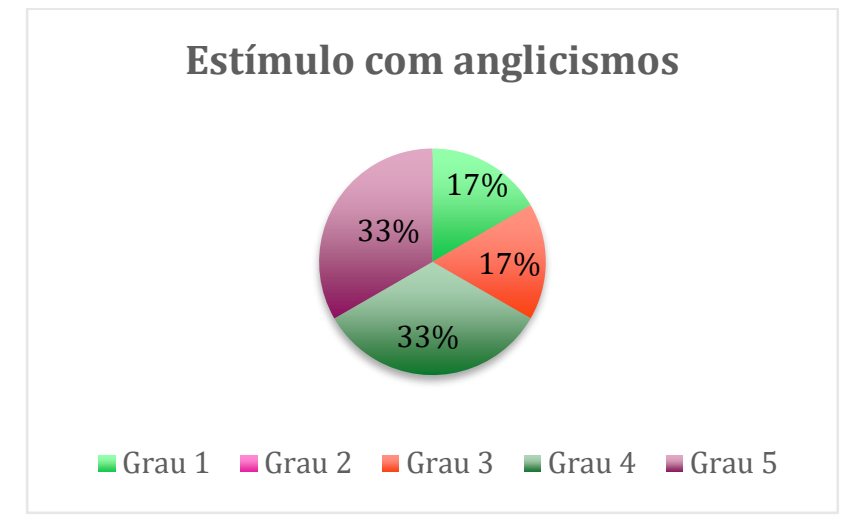

Fonte: dados da presente pesquisa

Já no gráfico acima, podemos verificar que as escolhas feitas sobre o mesmo quesito, referente ao estímulo com inserção de anglicismos apresenta mais avaliações concentradas nas opções mais positivas de avaliação, somando, ao todo, $66 \%$.

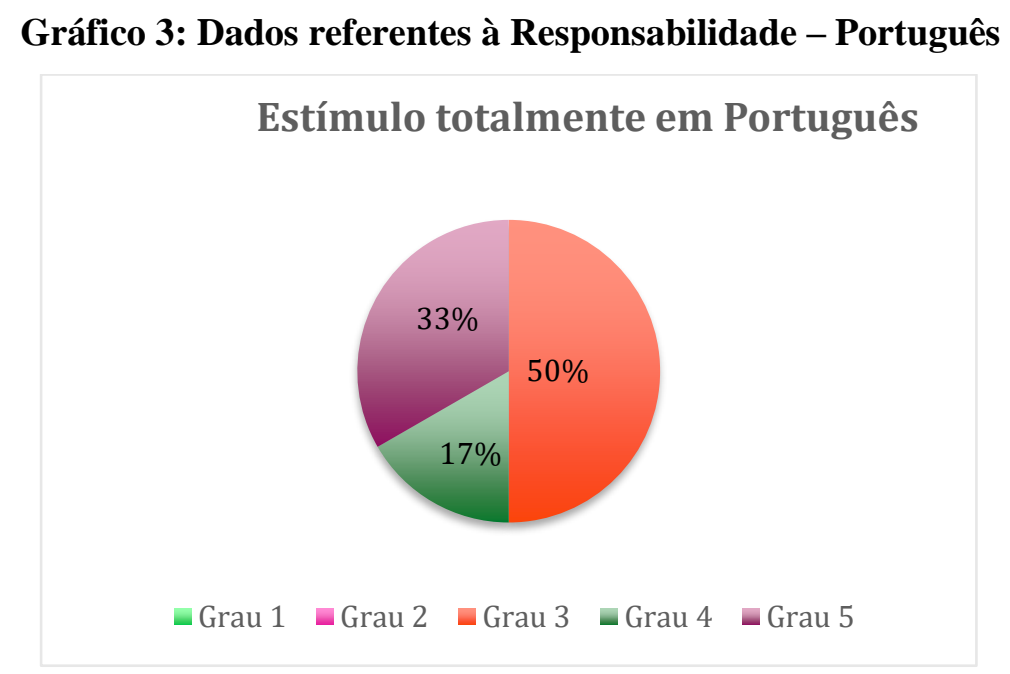

Fonte: Dados da presente pesquisa

De acordo com os dados do gráfico, com base na percepção das julgadoras de Letras, nota-se que o estímulo 1 obteve $50 \%$ das escolhas centradas na opção 3, ou seja, a metade das julgadoras opinaram que a falante é medianamente responsável. Porém, os outros $50 \%$ estão distribuídos entres as opções de avaliação mais positivas. 


\begin{tabular}{|c|c|}
\hline $\begin{array}{l}\text { Web Revista } \\
\text { ODIALETO }\end{array}$ & 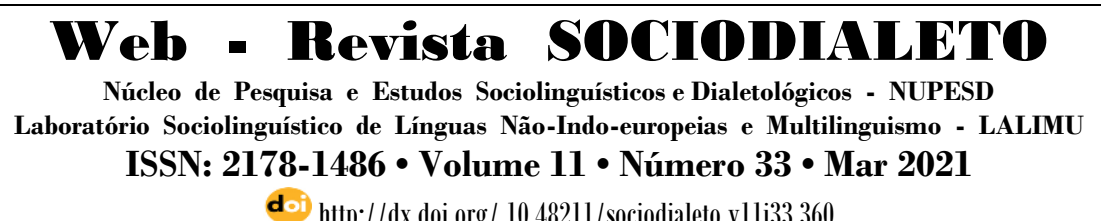 \\
\hline
\end{tabular}

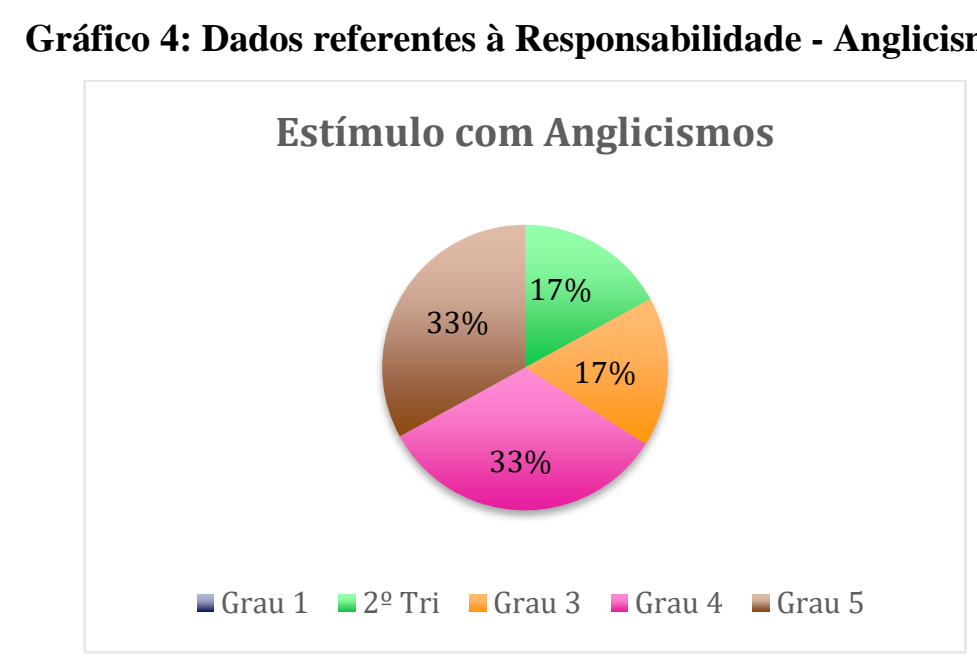

Fonte: dados da presente pesquisa

Por meio do gráfico, referente à fala com anglicismos, nota-se que, no que se refere à responsabilidade, há uma maior concentração de escolhas nas opções mais positivas, totalizando $66 \%$ das avaliações das juízas.

\section{Gráfico 5: Dados referentes à Elegância - Português}

\section{Estímulo totalmente em Português}

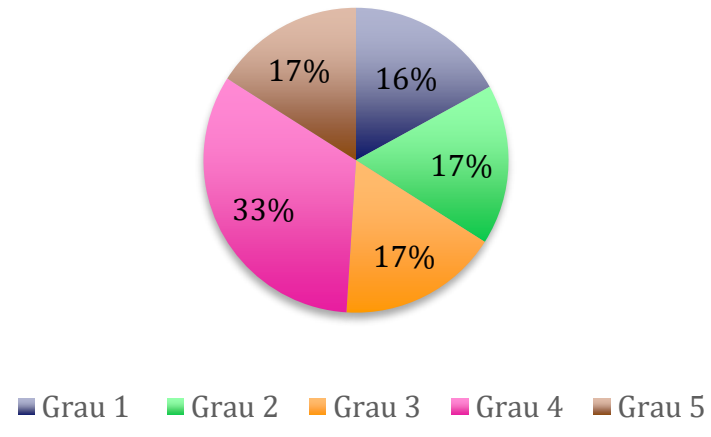

Fonte: dados da presente pesquisa

Em relação à elegância, ao observar o gráfico, percebemos que houve uma distribuição de escolhas em todas as opções, sobretudo na opção 4, que representa 


\begin{tabular}{|c|c|}
\hline $\begin{array}{r}\text { Web Revista } \\
\text { OODIALETO }\end{array}$ & 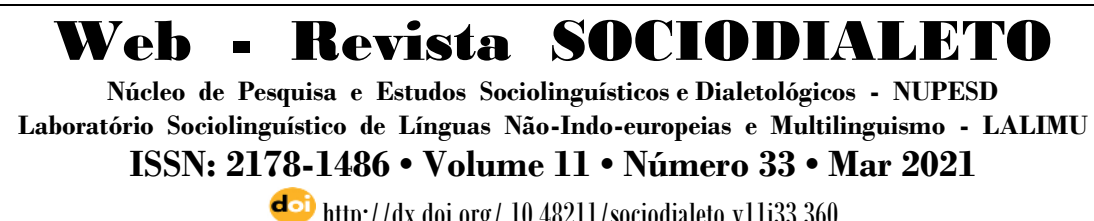 \\
\hline
\end{tabular}

$33 \%$ ao total. Além disso, 17\% optaram pela opção 5. Logo, a soma das opções simboliza 50\% das escolhas das julgadoras perante a fala apenas em português.

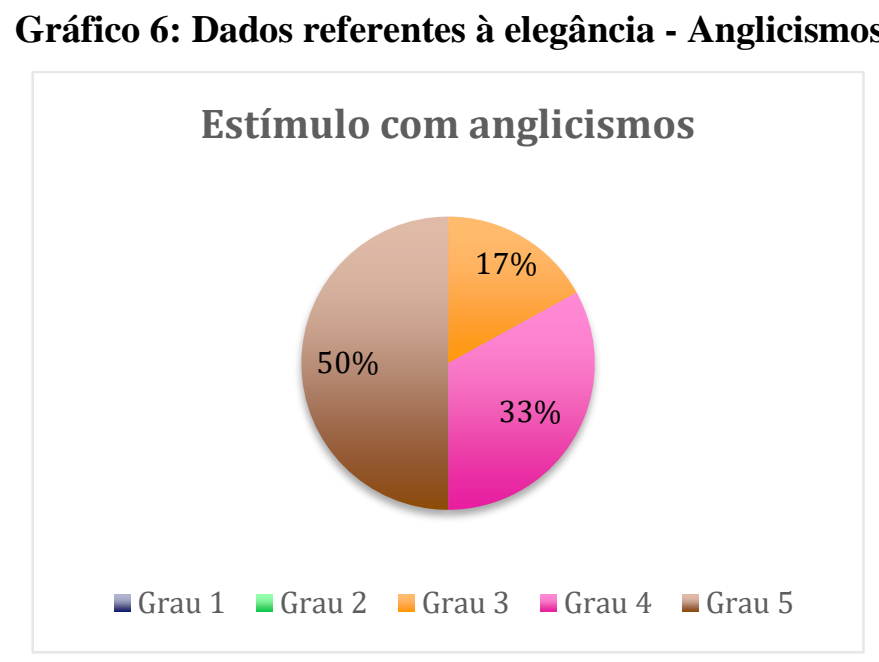

Fonte: dados da presente pesquisa

Em relação à fala com anglicismos, observa-se que, de acordo com o gráfico, houve uma oscilação menor entre as escolhas das julgadoras no que tange à elegância. Além disso, nota-se que mais da metade das escolhas, $83 \%$, concentram-se nas opções mais positivas.

Finalizada a análise dos dados em relação às percepções das acadêmicas de Letras sobre os dois estímulos, observa-se que a avaliação mais positiva em relação a todos os atributos, inteligência, responsabilidade e elegância, recaiu sobre o estímulo com anglicismos. Desse modo, para as acadêmicas de Letras, de acordo com os atributos utilizados no teste, um falante é visto com maior prestígio quando utiliza palavras em língua inglesa.

\section{2- Análise da percepção das acadêmicas de Matemática}

Serão expostos, nesta seção, os dados atinentes aos julgamentos das acadêmicas de Matemática, como demonstra o gráfico abaixo. 


\begin{tabular}{|c|c|}
\hline $\begin{array}{l}\text { Web Revista } \\
\text { SOG ODIALET0 }\end{array}$ & 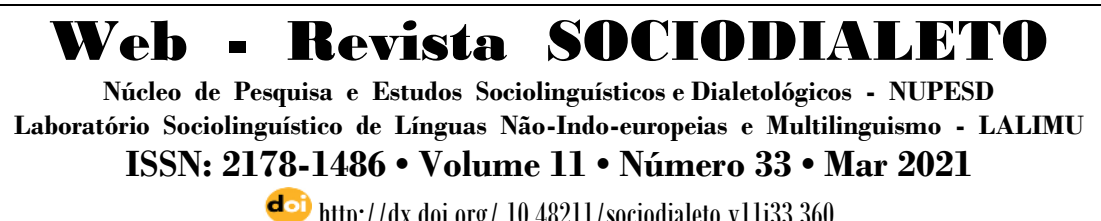 \\
\hline
\end{tabular}

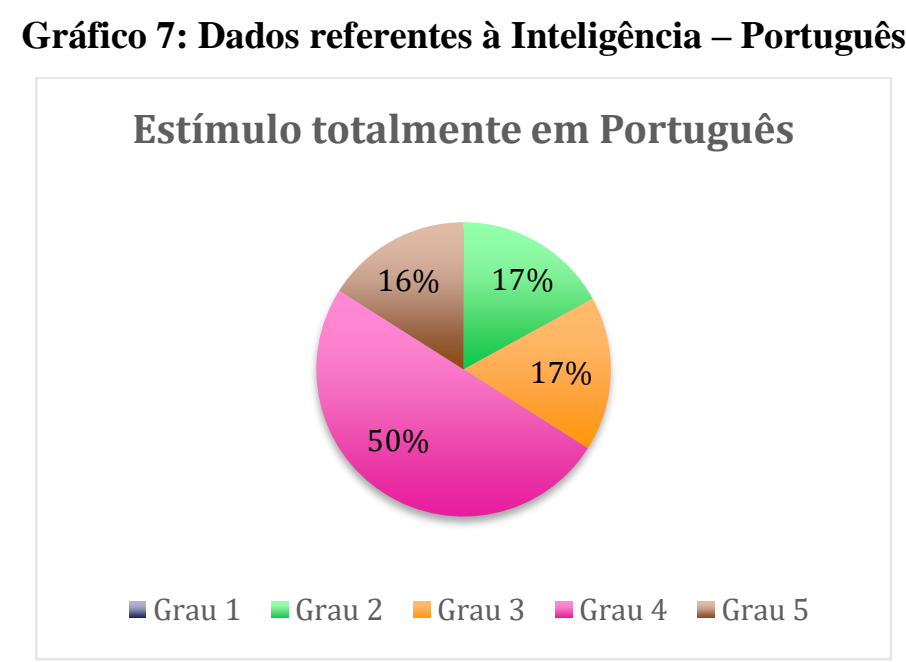

Fonte: dados da presente pesquisa

Ao observar o gráfico, no que se refere à inteligência, nota-se a avaliação das juízas concentrou-se nas opções 4 e 5 , que somam $66 \%$ do total, e remetem ao estímulo com palavras apenas do português.

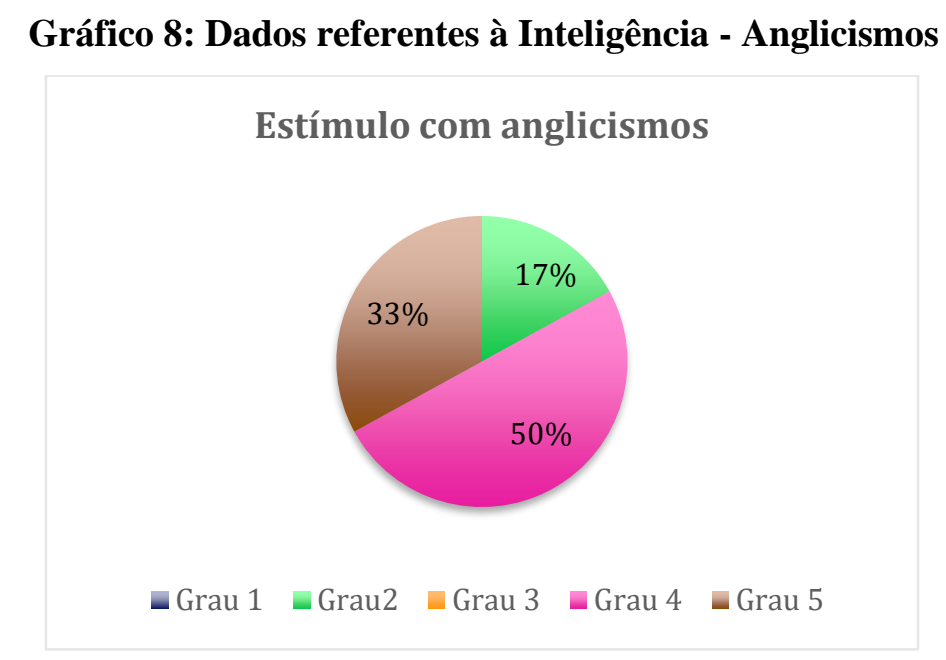

Fonte: dados da presente pesquisa

Ainda referente à inteligência, com base no gráfico, percebe-se que a maioria das avaliações também estão concentradas nas opções de avaliação mais positivas. Desse 


\begin{tabular}{|c|c|}
\hline $\begin{array}{l}\text { Web Revista } \\
\text { ODIALETO }\end{array}$ & 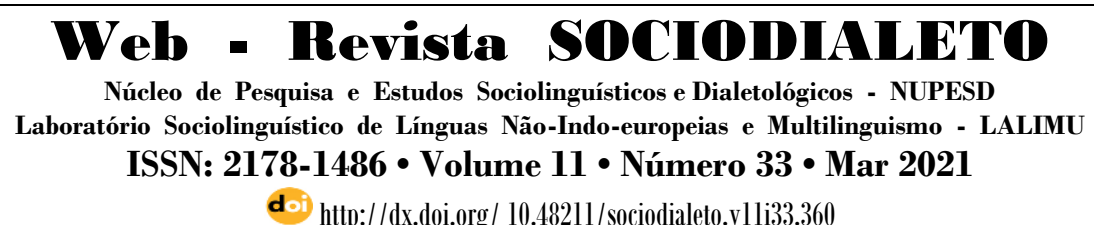 \\
\hline
\end{tabular}

modo, tem-se $83 \%$ das escolhas das julgadoras relacionadas ao estímulo com anglicismos.

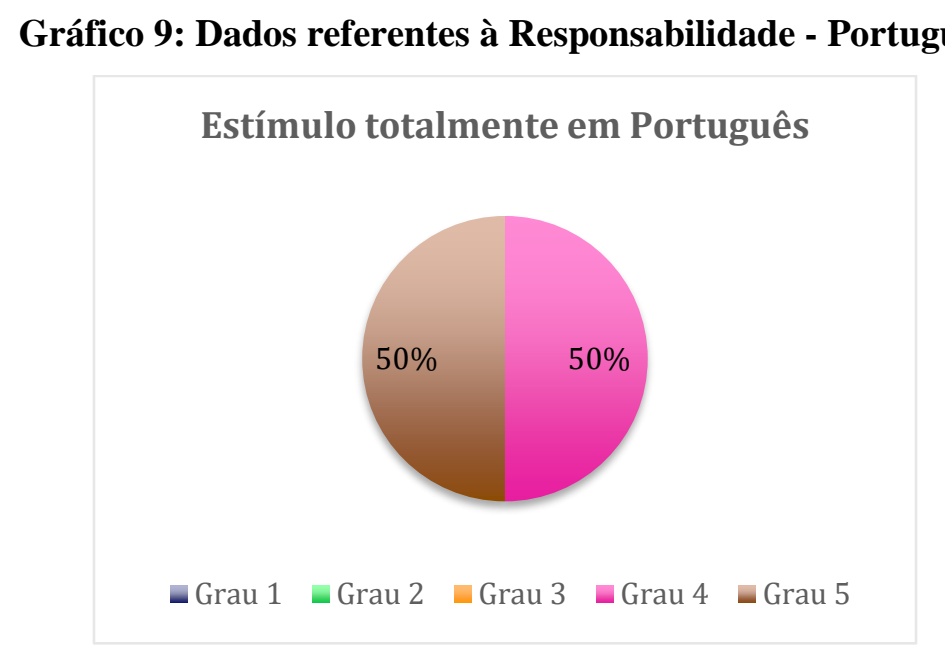

Fonte: dados da presente pesquisa

De acordo com os dados apresentados, no que diz respeito à responsabilidade, nota-se que as escolhas das julgadoras concentram-se apenas nas opções de avaliação mais positivas no que tange ao estímulo elaborado totalmente em Português.

Gráfico 10: Dados referentes à Responsabilidade - Anglicismos Estímulo com anglicismos

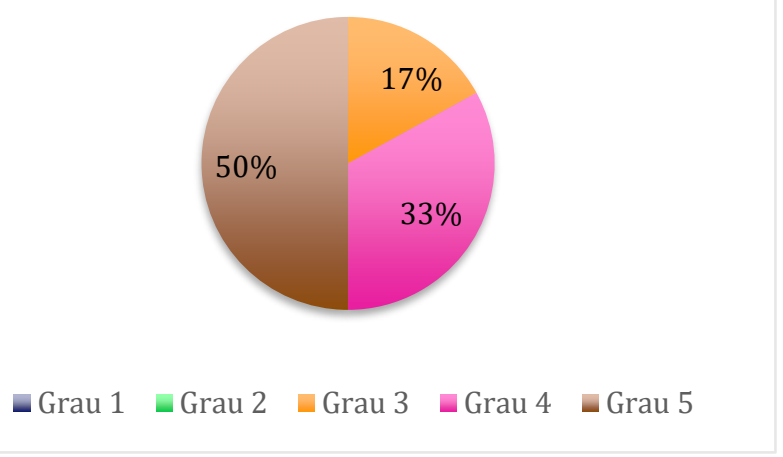

Fonte: dados da presente pesquisa 


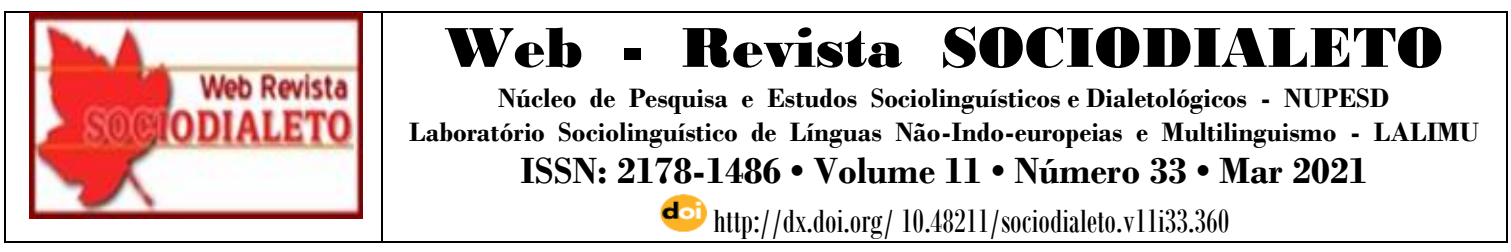

Nota-se que, de acordo com os dados apresentados no gráfico, referente à fala com anglicismos, há uma maior oscilação entre as escolhas das julgadoras sobre o atributo responsabilidade. No total, tem-se $83 \%$ das avaliações nas opções 4 e 5.

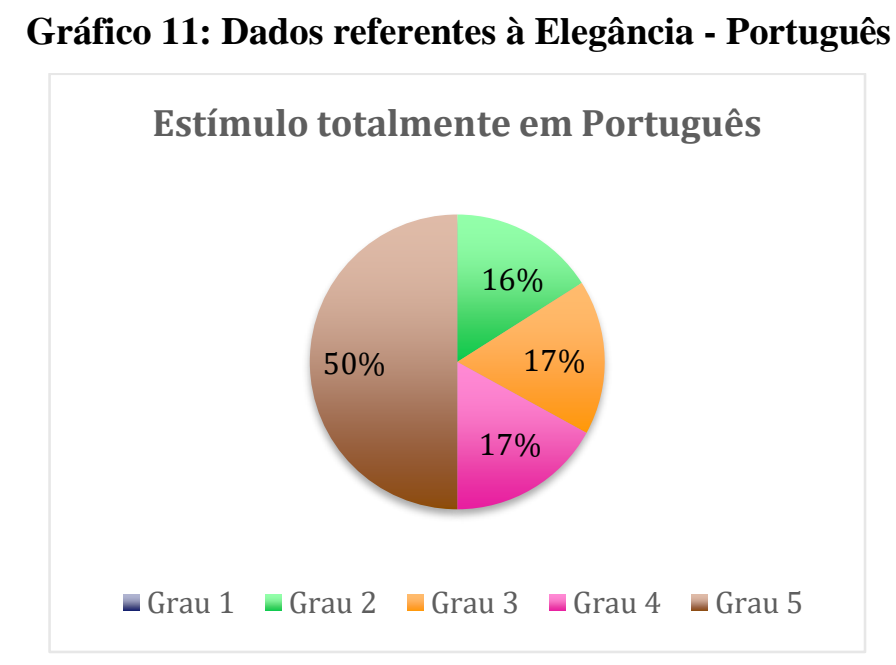

Fonte: dados da pressente pesquisa

Em relação à elegância, de acordo com os dados apresentados, 67\%, ou seja, mais da metade das escolhas feitas pelas julgadoras, concentram-se nas opções mais positivas, referentes ao estímulo elaborado totalmente em Português.

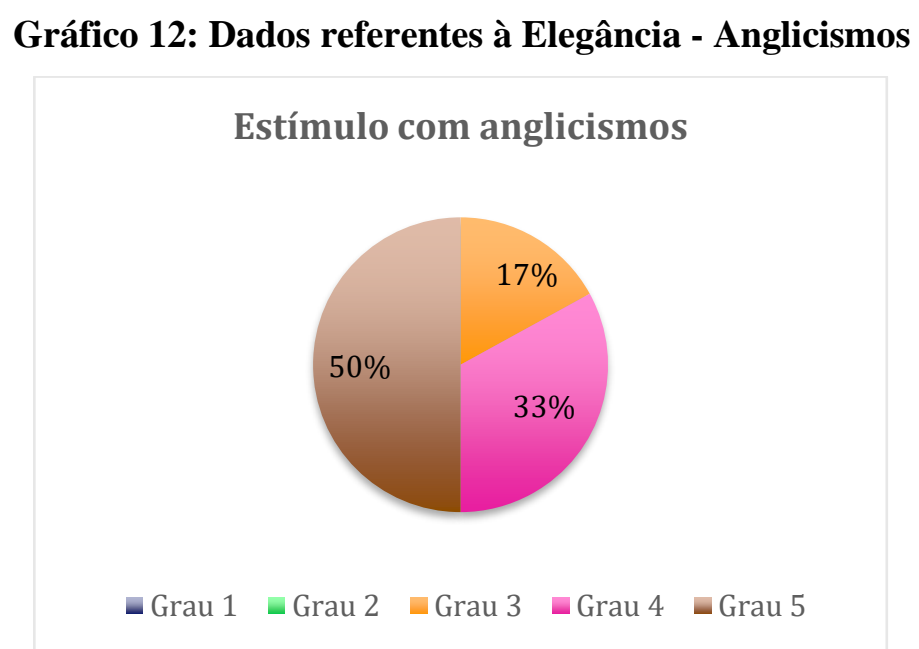

Fonte: dados da presente pesquisa 


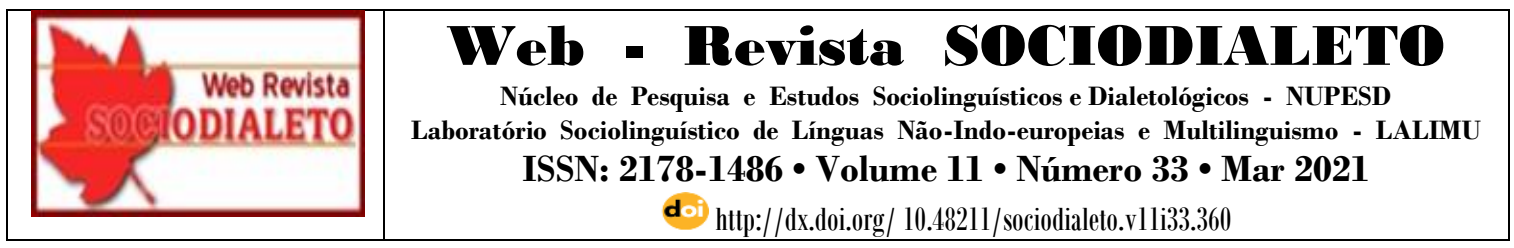

O gráfico referente ao estímulo com anglicismos mostra que $83 \%$ das escolhas das julgadoras concentram-se nas opções de avaliação mais positivas no que se refere à elegância, ao passo que $17 \%$ mostra-se indecisa quanto a esse atributo.

Concluída a análise das percepções feitas pelas acadêmicas de Matemática, notase que as juízas desse grupo julgaram de forma mais positiva, no que se refere ao estímulo em que constam palavras, somente o atributo responsabilidade. Os demais atributos, inteligência e elegância, foram atribuídos à fala com a inserção de anglicismos. Desse modo, observa-se que o nível de prestígio atribuído pelas acadêmicas de Matemática em relação ao estímulo com anglicismos foi menor em relação do que aquele observado nos dados das acadêmicas de Letras.

\section{CONSIDERAÇÕES FINAIS}

As atitudes linguísticas das participantes desta pesquisa, pertencentes a diferentes áreas do conhecimento, revelam diferentes comportamentos no que se refere à inserção de anglicismos no PB. Contudo, houve uma diferença no quesito responsabilidade, pois, para as acadêmicas de Letras, a fala com anglicismos soou mais responsável, enquanto, as acadêmicas de Matemática avaliaram como mais responsável o estímulo totalmente em português.

Tal fato, possivelmente, ocorreu devido às crenças linguísticas que cada grupo possui em relação à inserção de anglicismos na língua materna, o contato social que cada informante possui com a LI pode ter levado as juízas a demonstrar atitudes distintas.

Mediante as atitudes linguísticas tomadas pelas informantes, conclui-se que o inglês detém maior prestígio linguístico em relação ao português, quando se trata de pessoas que mantêm um contato com esta língua cotidianamente, a exemplo das acadêmicas de Letras. No entanto, no caso das acadêmicas de Matemática, provavelmente, por não terem contato com a visão científica da língua, proporcionada pela Linguística, foram mais propensas ao purismo linguístico. Por outro lado, isso não fez com que rejeitassem por completo o uso de anglicismos. 


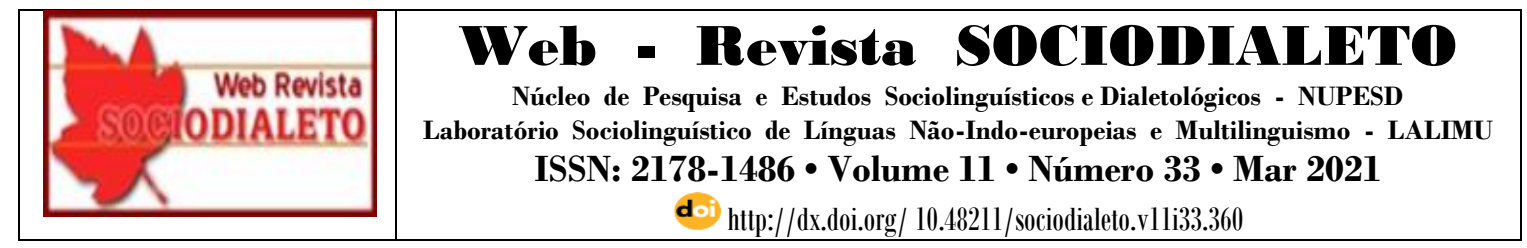

Além disso, as acadêmicas de Matemática contradisseram a hipótese aventada acerca de uma pessoa parecer mais inteligente ou responsável quando usa anglicismo, uma vez que avaliação desse grupo de juízas para tais atributos não foi tão positiva quanto aquela verificada pelas acadêmicas de Letras.

Logo, observa-se que processo de aceitação e/ou rejeição dos anglicismos no PB é condicionado por vários fatores socioculturais, tais como o maior ou menor contato com a Língua Inglesa e a formação acadêmica dos juízes. Além disso, nota-se que o uso dos estrangeirismos é um reflexo de um panorama mais amplo, tal como a dependência econômica de outros países, ou mesmo o desejo de reproduzir seus valores ou padrões culturais, como já aconteceu com os galicicismos (palavras em francês), na virada do século XVIII para o século XX e, mais recentemente, com os anglicismos, a partir do século XX.

Apesar de as acadêmicas de Matemáticas terem sido mais conservadoras em relação às suas crenças, ambas os grupos de juízas, conferiram mais prestígio ao uso de palavras em inglês. Desse modo, evidencia-se que a mudança linguística, expressa pela incorporação de anglicismos ao Português, deriva, antes de tudo, de uma mudança de hábitos, de valores e de visões de mundo dos falantes de PB.

\section{REFERÊNCIAS}

BAGNO, M. Cassandra. Fênix e outros mitos. In FARACO, C. A. (Org). Estrangeirismos: guerra em torno da língua. São Paulo: Parábola, 2001.

BAGNO, M. Preconceito linguístico: o que é, como se faz. São Paulo: Editora Loyola, 1999.

BIDERMAN, M. T. C. Teoria linguística: teoria lexical e linguística computacional. São Paulo: Martins Fontes, 2001.

CÂMARA, JR., J. M. Dicionário de linguística e gramática. Petrópolis/RJ: Vozes, 1986, p.102.

CARVALHO, N. Empréstimos linguísticos. São Paulo: Ática, 2002.

CARVALHO, N. Empréstimos linguísticos na língua portuguesa. São Paulo: Cortez, 2009. 


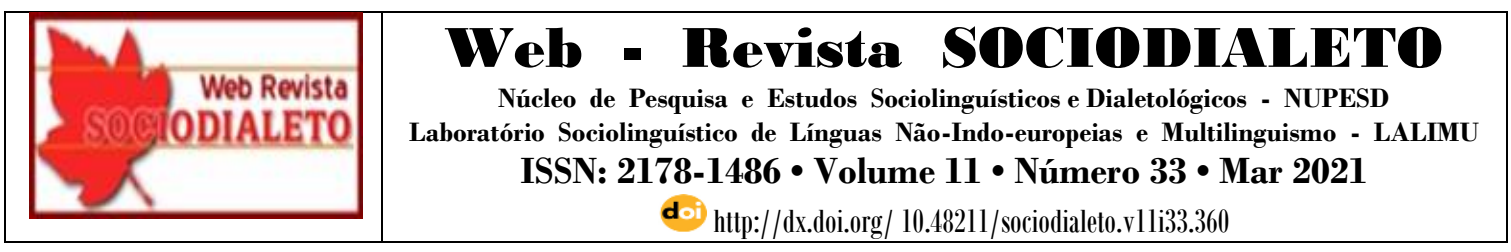

ECKERT, P. Linguistc Variation as Social Practice. Oxoford: Blackwell, 2000.

FARACO, C. A. (org.) Estrangeirismos: guerras em torno da língua. São Paulo: Parábola, 2001.

FERNÁNDEZ, M. F. Actitudes linguísticas. In: FERNÁNDEZ, M. F. Principios de Sociolingüítica y Sociología del lenguaje. $1^{\circ}$ edição, Córcega: Editora Ariel S.A., 1998, p. 88-192.

LABOV, W. Principles of linguistic change. Oxford: Blackwell, v. 1, 1994.

LABOV, W. Padrões sociolinguísticos. Trad. Marcos Bagno; Marta Scherre; Caroline Cardoso; São Paulo: Parábola, 2008 [1972], p. 19.

LAMBERT, W. E. A Social Psychology of Bilingualism. [1967] In: PAULSTON, C. PAULSTON, C. B.; TUCKER, G. R. (orgs.). Sociolinguistics: the essential readings. Malden, MA: Blackwell Publishing, 2003 [1967].

PAUlSTON, C. B.; TUCKER, G. R. (orgs.). Psicologia Social. 3. ed. Rio de Janeiro: Zahar Editores, 1972, p. 7.

RAJAGOPALAN, K. Por uma linguística crítica: linguagem, identidade e a questão ética. São Paulo: Parábola Editorial, 2003.

SANDMANN, A. J. Morfologia lexical. São Paulo: Contexto, 1997.

WEINRIECH, U.; LABOV, W.; HERZOG M. I. Fundamentos empíricos para teoria de mudança linguística. Trad. Marcos Bagno. São Paulo: Parábola Editorial, 2006 [1968] p. 125-126.

Recebido em: 31/10/2020 | Aprovado em: 19/01/2021. 